\title{
GAMBARAN STATUS GIZI ANAK BALITA DI PPA (PUSAT \\ PENGEMBANGAN ANAK) ID-127 DAN CSP (CHILD SURVIVAL PROGRAMME) CS 07 KELURAHAN RANOMUT MANADO
}

\author{
${ }^{1}$ Yusni Sugeha \\ ${ }^{2}$ Ronald I Ottay \\ ${ }^{2}$ Henry M F Palandeng
}

\author{
${ }^{1}$ Kandidat Skripsi Fakultas Kedokteran Universitas Sam Ratulangi Manado \\ ${ }^{2}$ Bagian Ilmu Kedokteran Pencegahan Fakultas Kedokteran \\ Universitas Sam Ratulangi Manado \\ Email: libraunie@yahoo.com
}

\begin{abstract}
Nutritional status is body condition that affected by food consumption and nutrient substance using. It is distinguished among bad nutrition, less nutrition and good nutrition status and it is measured by body mass index based on age as the one anthropometer index. Objective: The objectives of this research is to know a description of toddler's nutirional status at PPA ID - 127 (Chldren Development Center) and CSP CS-07 (Child Survival Programme) in Ranomut Subdistrict, Manado City. The research methodology is using descriptive analysis with doing survey. The research population is toddler $0-59$ month with 80 toddlers as sample and the respondent is the toddler's mother. Result: Based on anthropometer measurement with body mass indicator based on age, the results are 11 toddlers $(13,5 \%)$ with less nutrition status, 69 toddlers $(86,5 \%)$ with good nutrition status while toddle with bad nutrition status is nothing.
\end{abstract}

Keywords: Nutrional status, toddlers.

Abstrak: Status Gizi adalah keadaan tubuh sebagai akibat konsumsi makanan dan penggunaan zat-zat gizi. Dibedakan antara status gizi buruk, kurang, dan lebih yang diukur dengan menggunakan salah satu indeks antopometri yaitu indeks berat badan menurut umur (BB/U). Tujuan: Tujuan dari penelitian ini adalah untuk mengetahui gambaran status gizi anak balita di PPA ID-127 (Pusat Pengembangan Anak) dan CSP CS-07 (Child Survival Programme) di Kelurahan Ranomut Manado. Metode penelitian yang digunakan adalah penelitian deskriptif dengan mengadakan survey. Populasi penelitian adalah balita 0-59 bulan dengan sampel sebanyak 80 anak balita, responden dalam penelitian ini adalah ibu dari anak balita yang menjadi sampel penelitian. Hasil: Berdasarkan pengukuran antopometri dengan indikator berat badan menurut umur $(\mathrm{BB} / \mathrm{U})$ didapatkan anak balita dengan status gizi kurang sebanyak 11 orang $(13,5 \%)$, gizi baik sebanyak 69 orang $(86,5 \%)$ sedangkan gizi buruk tidak ada.

Kata kunci: Status gizi, anak balita.

Pencapaian pembangunan MDGs (Millennium Development Goals) terkait upaya peningkatan kelangsungan hidup anak di masa mendatang, pada tahun 2015 setiap negara harus berupaya terus untuk menurunkan separuh jumlah penduduk miskin dan kelaparan. Tujuan MDGs menempatkan manusia sebagai fokus utama pem- 
bangunan yang mencakup semua komponen kegiatan, termasuk kesehatan, yang tujuan akhirnya ialah kesejahteraan masyarakat. Di Indonesia pencapaian MDGs dengan indikator-indikator paling menentukan untuk memberantas kemiskinan dan kelaparan adalah prevalensi gizi kurang dan gizi buruk. Prevalensi gizi kurang menurun secara signifikan dari 31\% (1989) menjadi $17,9 \%$ (2010). Demikian pula prevalensi gizi buruk menurun dari 12,8 \% (1995) menjadi 4,9\% (2010). Kecenderungan ini menunjukan target penurunan prevalensi gizi kurang dan gizi buruk menjadi 15\% dan $3,5 \%$ pada 2015 , diharapkan dapat tercapai. ${ }^{1}$

Kurang gizi menyebabkan gangguan pertumbuhan dan perkembangan fisik maupun mental, mengurangi tingkat kecerdasan, kreativitas, dan produktifitas penduduk. Indonesia menghadapi masalah gizi yang cukup memprihatinkan, ini dapat dilihat berdasarkan Survei Sosial Ekonomi Nasional (Susenas) tahun 2007, terdapat 13\% balita dengan status gizi kurang dan 5,4\% balita berstatus gizi buruk dari 18 juta balita. Menurut Depkes 2008, jumlah balita penderita malnutrisi pada tahun 2007 yaitu 4,1 juta jiwa. Sebanyak 3,38 juta jiwa berstatus gizi kurang dan 755 ribu termasuk kategori resiko gizi buruk. ${ }^{2,3}$

Berdasarkan latar belakang yang ada peneliti ingin mengetahui sejauh mana gambaran status gizi balita dengan pola pemberian makanan yang menunjang gizi dari balita tersebut di PPA ID-127 (Pusat Pengembangan Anak) dan CSP CS-07 (Child Survive Programme) di Kelurahan Ranomut.

\section{METODE PENELITIAN}

Penelitian ini bersifat deskriptif dengan mengadakan survey yang bertujuan untuk mengetahui gambaran status gizi anak balita di PPA ID-127 (Pusat Pengembangan Anak) dan CSP CS-07 (Child Survival Programme) Kelurahan Ranomut Manado. Waktu penelitian direncanakan dari bulan November 2011 - Januari 2012. Sampel diambil dari seluruh anak balita yang berada di PPA ID 127 (Pusat Pengembangan Anak) dan CSP CS-07 (Child Survival Pro-gramme) kelurahan Ranomut dengan jumlah populasi 80 orang anak balita. Sampel sama dengan jumlah populasi. Pengolahan data dilakukan secara manual dan meng-gunakan komputer. Data yang dikumpulkan akan disajikan dalam bentuk tabel distribusi frekuensi dan tulisan.

\section{HASIL}

Berdasarkan hasil penelitian di PPA ID-127 (Pusat Pengembangan Anak) dan CSP CS-07 (Child Survival Programme) Kelurahan Ranomut Manado diperoleh data yang disajikan dalam bentuk tabel distribusi sebagai berikut:

Dari hasil survey yang dilaksanakan di PPA ID-127 dan CSP 07 kelurahan Ranomut di peroleh jumlah anak balita sebanyak 80 orang. Pada tabel dibawah ini didapatkan gambaran mengenai keadaan anakanak balita tersebut. Distribusi anak balita menurut jenis kelamin terlihat bahwa jumlah anak laki-laki lebih banyak dari perempuan dengan jumlah anak laki-laki 45 orang $(56,5 \%)$ dan jumlah anak perempuan 35 orang $(43,5 \%)$. Jelasnya dapat dilihat pada tabel 1 berikut.

Tabel 1. Distribusi anak balita menurut jenis kelamin

\begin{tabular}{ccc}
\hline Jenis kelamin & n & \% \\
\hline Laki-laki & 45 & 56,5 \\
Perampuan & 35 & 43,5 \\
\hline Jumlah & 80 & 100 \\
\hline
\end{tabular}

Dari distribusi anak balita menurut umur terlihat kelompok umur $0-12$ bulan yaitu 9 orang $(11,5 \%)$ ), kelompok umur 13 24 bulan yaitu 12 orang (15\%)), kelompok umur 25-36 bulan yaitu 17 orang $(21,5 \%)$, kelompok umur 37-48 bulan yaitu 12 orang (15\%), sedangkan kelompok umur 49-59 bulan merupakan kelompok umur paling terbanyak yaitu 30 orang $(37 \%)$. Dapat dilihat pada Tabel 2 berikut. 
Tabel 2. Distribusi anak balita menurut umur.

\begin{tabular}{lcl}
\hline Umur (bulan) & $\mathbf{n}$ & $\mathbf{\%}$ \\
\hline $0-12$ & 9 & 11,5 \\
$13-24$ & 12 & 15 \\
$25-36$ & 17 & 21,5 \\
$37-48$ & 12 & 15 \\
$49-59$ & 30 & 37 \\
\hline \multicolumn{1}{c}{ Jumlah } & 80 & 100 \\
\hline
\end{tabular}

Berdasarkan hasil pengukuran antopometri BB/U didapatkan 69 orang (86,5\%) mempunyai gizi yang baik dan 11 orang $(13,5 \%)$ memiliki status gizi kurang. Jelasnya dilihat pada tabel 3 berikut.

Tabel 3. Status gizi menurut BB/U.

\begin{tabular}{lcc}
\hline Status gizi & n & \% \\
\hline Gizi baik & 69 & 86,5 \\
Gizi kurang & 11 & 13,5 \\
Gizi buruk & - & - \\
\hline Jumlah & 80 & 100 \\
\hline
\end{tabular}

Status gizi menurut umur terlihat bahwa kebanyakan balita yang mempunyai gizi baik terdapat pada kelompok umur 4959 bulan yaitu 28 orang $(40,6 \%)$ dan gizi kurang pada kelompok umur 25-36 bulan sebanyak lima orang $(4,4 \%)$. Untuk lebih jelasnya dapat dilihat pada tabel 4 berikut.

Tabel 4. Status gizi menurut umur.

\begin{tabular}{lcccccc}
\hline $\begin{array}{l}\text { Umur } \\
\text { (bulan) }\end{array}$ & \multicolumn{2}{c}{$\begin{array}{c}\text { Gizi } \\
\text { baik }\end{array}$} & \multicolumn{2}{c}{$\begin{array}{c}\text { Gizi } \\
\text { kurang }\end{array}$} & \multicolumn{2}{c}{$\begin{array}{c}\text { Gizi } \\
\text { buruk }\end{array}$} \\
& n & \% & n & \% \\
\hline $0-12$ & 9 & 13,0 & - & - & - & - \\
$13-24$ & 9 & 13,0 & 3 & 27,2 & - & - \\
$25-36$ & 12 & 17,4 & 5 & 45,4 & - & - \\
$37-48$ & 11 & 16,4 & 1 & 9,1 & - & - \\
$49-59$ & 28 & 40,6 & 2 & 18,1 & - & - \\
\hline Jumlah & 69 & 100 & 11 & 100 & - & - \\
\hline
\end{tabular}

Dari status gizi yang anak balita menurut jenis kelamin terlihat bahwa kebanyakan gizi baik terlihat pada anak laki-laki yaitu 38 orang $(55,7 \%)$ dan pada gizi kurang juga terbanyak pada anak laki-laki yaitu tujuh orang $(63,7 \%)$. Dapat terlihat pada tabel 5 berikut.
Tabel 5. Status gizi anak balita menurut jenis kelamin.

\begin{tabular}{lccc}
\hline Status Gizi & & n & $\mathbf{\%}$ \\
\hline Gizi Baik & L & 38 & 55.7 \\
\multirow{4}{*}{ Gizi Kurang } & P & 31 & 44.3 \\
& L & 7 & 63.7 \\
Gizi Buruk & P & 4 & 36.3 \\
& L & - & - \\
& P & - & - \\
\hline
\end{tabular}

Distribusi responden menurut umur sebagian besar golongan umur 18 sampai 40 tahun, yaitu 74 orang $(92,5 \%)$ dan sisanya golongan umur lebih dari 40 tahun, yaitu enam orang $(7,5 \%)$. Hal ini dapat dilihat pada Tabel 6 berikut.

Tabel 6. Distribusi karateristik responden menurut umur.

\begin{tabular}{ccc}
\hline Umur Ibu-ibu & $\mathbf{N}$ & $\mathbf{\%}$ \\
\hline $18-40$ & 74 & 92,5 \\
$>40$ tahun & 6 & 7,5 \\
\hline Jumlah & 80 & 100 \\
\hline
\end{tabular}

Berdasarkan distribusi responden menurut tingkat pendidikan hasil penelitian sebagian besar orang tua yang pendidikannya SMA, yaitu 48 orang $(60 \%)$, berpendidikan SMP, yaitu 20 orang $(25 \%)$ dan berpendidikan SD, yaitu 12 orang (15\%). Dapat dilihat pada tabel 7 dibawah ini.

Tabel 7. Distribusi responden menurut pendidikan.

\begin{tabular}{lcc}
\hline Pendidikan & n & \% \\
\hline SD & 12 & 15 \\
SMP & 20 & 25 \\
Menengah (SMA) & 48 & 60 \\
Diploma/S1 & - & - \\
\hline \multicolumn{1}{c}{ Jumlah } & 80 & 100 \\
\hline
\end{tabular}

Sebagian besar terdiri dari ibu rumah tangga yaitu 77 orang $(96,5 \%)$, dan lainnya swasta yaitu tiga orang $(3,5 \%)$. Distribusi responden menurut pekerjaan dapat terlihat pada tabel 8 di bawah ini. 
Tabel 8 Distribusi menurut pekerjaan.

\begin{tabular}{lcc}
\hline Jenis pekerjaan & n & \% \\
\hline Ibu Rumah Tangga & 77 & 96,5 \\
Swasta & 3 & 3,5 \\
\hline \multicolumn{1}{c}{ Jumlah } & 80 & 100 \\
\hline
\end{tabular}

Dari hasil survey bahwa kebanyakan ibu-ibu melahirkan secara spontan dengan 69 orang $(86,5 \%)$ dan secara operasi yaitu 11 0rang (13,5\%). Dapat dilihat pada tabel 9 dibawah ini.

Tabel 9. Distribusi cara persalinan ibu.

\begin{tabular}{lcc}
\hline Persalinan & n & \% \\
\hline Spontan & 69 & 86,5 \\
Operasi & 11 & 13,5 \\
\hline \multicolumn{1}{c}{ Jumlah } & 80 & 100 \\
\hline
\end{tabular}

Dari hasil wawancara didapatkan bahwa 44 orang $(55 \%)$ persalinan ditolong oleh dokter, 28 orang $(35 \%)$ ditolong oleh bidan dan sisanya oleh dukun terlatih delapan orang $(10 \%)$. Lihat pada tabel 10 berikut.

Tabel 10. Penolong persalinan.

\begin{tabular}{lcc}
\hline Penolong & n & \% \\
\hline Dokter & 44 & 55 \\
Bidan & 28 & 35 \\
Dukun Terlatih & 8 & 10 \\
\hline \multicolumn{1}{c}{ Jumlah } & 80 & 100 \\
\hline
\end{tabular}

Terlihat paling banyak ibu-ibu memilih melahirkan di rumah sakit yaitu 45 orang $(56,5 \%)$, klinik bersalin tujuh orang $(8,5 \%)$, puskesmas 19 orang $(23,5 \%)$ dan di rumah sendiri sembilan orang $(11,5 \%)$. Dapat dilihat pada tabel 11 berikut ini.

Tabel 11. Tempat ibu melahirkan.

\begin{tabular}{lcc}
\hline Tempat melahirkan & n & \% \\
\hline Rumah sakit & 45 & 56,5 \\
Klinik bersalin & 7 & 8,5 \\
Puskesmas & 19 & 23,5 \\
Rumah sendiri & 9 & 11,5 \\
\hline \multicolumn{1}{c}{ Jumlah } & 80 & 100 \\
\hline
\end{tabular}

Dari hasil penelitian didapatkan bahwa hanya 64 orang $(80 \%)$ memberikan ASI pada anaknya, sedangkan 16 orang $(20 \%)$ tidak diberikan. Untuk lebih jelas lihat pada tabel 12 berikut.

Tabel 12. Pemberian ASI.

\begin{tabular}{lcc}
\hline Tindakan & n & \% \\
\hline Diberikan & 64 & 80 \\
Tidak diberikan & 16 & 20 \\
\hline \multicolumn{1}{c}{ Jumlah } & 80 & 100 \\
\hline
\end{tabular}

Dari hasil wawancara terlihat bahwa pendapat ibu mengenai pemberian ASI terbanyak yaitu ASI cocok untuk bayi 56 orang $(70 \%)$ sedangkan anjuran dokter/bidan 16 orang $(20 \%)$ dan sisanya karena PASI mahal delapan 0rang (10\%). Dapat dilihat pada tabel 13 berikut.

Tabel 13. Pendapat ibu mengenai pemberian ASI.

\begin{tabular}{lcc}
\hline Alasan responden & $\mathbf{n}$ & $\mathbf{\%}$ \\
\hline ASI cocok untuk bayi & 56 & 70 \\
Anjuran dokter & 16 & 20 \\
PASI mahal & 8 & 10 \\
\hline \multicolumn{1}{c}{ Jumlah } & 80 & 100 \\
\hline
\end{tabular}

Berdasarkan hasil penelitian terlihat bahwa umur pertama diberikan asi terbanyak 0-2 jam yaitu 67 orang $(83,5)$. Frekuensi menyusui sehari adalah setiap kali bayi menangis 52 orang (65\%). Untuk lebih jelasnya lihat pada tabel 14 berikut.

Tabel 14. Pola pemberian ASI anak balita.

\begin{tabular}{|c|c|c|c|}
\hline \multicolumn{2}{|c|}{ Pendapat } & \multirow[t]{2}{*}{$\mathbf{n}$} & \multirow[t]{2}{*}{$\%$} \\
\hline & Umurpertama pemberian $A$ & & \\
\hline & $0-2$ jam & 67 & 83.5 \\
\hline & 2-24 jam & 9 & 11.5 \\
\hline & $>24 \mathrm{jam}$ & 4 & 5 \\
\hline \multicolumn{4}{|c|}{$\begin{array}{l}\text { 2. Frekuensi penyusuan per } \\
\text { hari }\end{array}$} \\
\hline & $<5$ kali & 24 & 30 \\
\hline & $>5$ kali & 4 & 5 \\
\hline & Setiap kali bayi menagis & 52 & 65 \\
\hline 3. & Lamanya menyusui & & \\
\hline 4. & Sampai bayi kenyang & 68 & 85 \\
\hline & $<5$ mnit & 12 & 15 \\
\hline
\end{tabular}


Dari hasil survey terlihat bahwa yang memberikan petunjuk pemberian ASI di PPA ID-127 dan CSP 07 kelurahan Ranomut adalah ibu-ibu sendiri. Lihat pada tabel 15 berikut.

Tabel 15. Umur penghentian pemberian ASI.

\begin{tabular}{lcc}
\hline \multicolumn{1}{c}{ Umur (bulan) } & n & \% \\
\hline$<3$ & 2 & 2,5 \\
$3-6$ & 3 & 3,75 \\
$6-12$ & 5 & 6,25 \\
$12-16$ & 7 & 8,75 \\
$16-24$ & 7 & 8,75 \\
$25-36$ & 34 & 42,5 \\
$37-48$ & 15 & 17,5 \\
$49-59$ & 8 & 10 \\
\hline \multicolumn{1}{r}{ Jumlah } & 80 & 100 \\
\hline
\end{tabular}

Berdasarkan hasil penelitian terlihat bahwa alasan responden menghentikan ASI pada anak balita terbanyak pada produksi ASI kurang/habis yaitu 62 orang $(77,5 \%)$, sedangkan lainnya karena ibu sakit lima orang $(6,5 \%)$ dan balita tidak mau menetek lagi 13 orang $(16,5)$ dapat terlihat pada tabel 16 berikut.

Tabel 16. Alasan responden menghentikan pemberian ASI.

\begin{tabular}{lcc}
\hline Alasan & n & \% \\
\hline ASI kurang & 62 & 77,5 \\
Ibu kerja & - & - \\
Ibu sakit & 5 & 6,5 \\
Balita tidak mau & 13 & 16,5 \\
menetek lagi & & \\
\hline Jumlah & 80 & 100 \\
\hline
\end{tabular}

Dari hasil penelitian terlihat bahwa kebanyakan pemberian PASI adalah pada umur $>12$ bulan, yaitu sebanyak 31 orang $(38,5 \%)$ dan ada juga diberikan sejak lahir yaitu 8 orang $(10 \%)$. Data pemberian PASI sesuai golongan umur dapat terlihat sebagai berikut pada tabel 17 berikut.

Dari hasil wawancara didapatkan bahwa anak balita yang diberi PASI dengan alasan produksi ASI kurang/habis yaitu 65 orang $(81,5 . \%)$ sisanya adalah anjuran dokter 15 orang $(18,5 \%)$. Untuk lebih jelasnya dapat terlihat pada tabel 18 berikut.
Tabel 17. Umur pemberian PASI.

\begin{tabular}{lcc}
\hline Umur (bulan) & n & \% \\
\hline Sejak lahir & 8 & 10 \\
$1-3$ & 6 & 7,5 \\
$4-6$ & 6 & 7,5 \\
$7-12$ & 29 & 36,5 \\
$>12$ & 31 & 38,5 \\
\hline \multicolumn{1}{c}{ Jumlah } & 80 & 100 \\
\hline
\end{tabular}

Tabel 18. Alasan pemberian PASI.

\begin{tabular}{lcc}
\hline Alasan Responden & n & \% \\
\hline Produksi ASI kurang/habis & 65 & 81,5 \\
Ibu kerja & - & - \\
Anjuran dokter/bidan & 15 & 18,5 \\
Ibu sakit & - & - \\
\hline Jumlah & 80 & 100 \\
\hline
\end{tabular}

Dari hasil penelitian terlihat bahwa umur pertama kali pemberian makanan tambahan terbanyak pada umur 5-6 bulan yaitu 27 orang $(33,5 \%)$. Lihat pada tabel 19 berikut.

Tabel 19. Umur pertama kali memberi makanan tambahan.

\begin{tabular}{lll}
\hline Umur (bulan) & n & \% \\
\hline$<4$ & 12 & 15 \\
$5-6$ & 27 & 33,5 \\
$7-12$ & 24 & 30 \\
$>12$ & 17 & 21,5 \\
\hline Jumlah & 80 & 100 \\
\hline
\end{tabular}

\section{BAHASAN}

Hasil penelitian yang dilaksanakan di PPA (Pusat Pengembangan Anak) ID-127 dan CSP-07 (Child Survival Programme) di kelurahan Ranomut didapat jenis kelamin laki-laki terbanyak yaitu 45 orang $(56,5 \%)$, sedangkan anak perempuan 35 orang $(43,5 \%)$. Jumlah anak berdasarkan distribusi umur ditemukan 0-12 bulan sebanyak sembilan orang (11,5\%), 13-24 bulan sebanyak 12 orang $(15 \%), 25-26$ bulan sebanyak 17 orang $(21,5 \%), 37-48$ bulan sebanyak 12 orang $(15 \%)$ dan $47-59$ bulan 30 orang (37\%). Pada umur tertentu pria dan wanita sangat berbeda dalam ukuran besar, kecepatan tumbuh, proporsi jasmani dan lainnya. Namun pada balita hal tersebut tidak terlalu bermakna karena hal tersebut 
akan sangat berpengaruh ketika memasuki masa adolesensi (masa remaja. ${ }^{4}$

Hasil penelitian status gizi di PPA (Pusat Pengembangan Anak) ID-127 dan CSP CS-07 (Child Survival Programme) di Kelurahan Ranomut dengan menggunakan indeks $\mathrm{BB} / \mathrm{U}$ (berat badan/umur) diklasifikasikan dalam empat kategori yaitu status gizi lebih baik, gizi baik, gizi kurang dan gizi buruk. Dari klasifikasi tersebut ditemukan balita dengan status gizi baik 69 orang $(85,5 \%)$, gizi kurang 11 orang $(13,5 \%)$. Berarti dalam penelitian ini status gizi terbanyak adalah balita dengan status gizi baik, dibandingkan dengan penelitian yang dilakukan oleh Iriani pakpahan mengenai gambaran status gizi anak balita di wilayah kerja Puskesmas Wonasa dengan hasil penelitian prevalensi gizi kurang sebanyak 23 orang $(23,9 \%)$, gizi buruk enam orang $(6,2 \%)$ dan gizi baik sebanyak 63 orang $(65,7 \%)$ lebih tinggi dari keadaan status gizi balita yang terdapat di PPA ID 127 (Pusat Pengembangan Anak) dan CSP CS07 (Child Survival Programme) kelurahan Ranomut. Hal ini kemungkinan ditunjang dari latar belakang tingkat pendidikan orang tua yang dirasa cukup untuk memiliki pengetahuan tentang gizi serta telah memiliki kesadaran akan kesehatan anak. Sedangkan status gizi kurang maupun buruk kemungkinan karena anak baru mengalami penyakit infeksi yang bias menyebabkan anoreksia, yaitu suatu keadaan dimana anak tidak memiliki nafsu makan dan dapat memyebabkan penurunan berat badan. ${ }^{5} \mathrm{Di}$ lihat dari tingkat pendidikan responden dalam penelitian ini yang terendah yaitu SD sebanyak 12 orang (15\%), SMP sebanyak 20 orang $(25 \%)$ dan tingkat pendidikan tertinggi yaitu SMA 48 orang $(60 \%)$. Tingkat pendidikan berpengaruh juga terhadap sikap dan perilaku sehat. Masyarakat dengan tingkat pendidikan rendah akan lebih baik mempertahankan tradisi yang berhubungan dengan makanan, sehingga sulit menerima informasi baru dalam bidang gizi. ${ }^{6}$ Hal ini menyebabkan ibu-ibu kurang mengetahui bagaimana mengatur pola makan kepada anak balitanya.

Responden pada penelitian ini umum- nya tidak mempunyai pekerjaan dan hanya sebagai Ibu Rumah Tangga yaitu sebanyak 77 orang $(96,5 \%)$ dan pegawai swasta hanya tiga orang $(3,5 \%)$. dapat disimpulkan sebagian besar ibu-ibu dari balita di PPA (Pusat Pengembangan Anak) ID-127 dan CSP CS-07 (Child Survival Programme) di kelurahan Ranomut adalah IRT (Ibu Rumah Tangga).

Dari riwayat kehamilan dan persalinan didapatkan sebagian besar lain secara normal yang semuanya lahir cukup bulan. Kebanyakan penolong persalinan oleh dokter sebanyak $55 \%$, sebagian di tangani oleh bidan sebanyak $35 \%$ dan ada pula yang ditangani oleh dukun terlatih karena kekurangan biaya dan harga terjangkau. Sehingga informasi tentang gizi sejak masa kehamilan dan menyusui tidak diperoleh. Penghentian pemberian ASI terbanyak pada kelompok umur 25-36 bulan sebanyak 42,5\%. Hal ini berhubungan dengan keadaan produksi ASI yang kurang/habis. ${ }^{7}$

Pemberian PASI pada semua umur akan tetapi kebanyakan pada umur lebih dari 12 bulan sebanyak 38,5\% dengan alasan produksi ASI habis/kurang. Sedangkan pemberian makanan tambahan juga telah diberikan pada umur 5-6 bulan. Hal ini karena pemberian makanan pendamping ASI harus setelah usia empat bulan, karena jika diberikan terlalu dini akan menurunkan konsumsi ASI dan bayi mengalami gangguan penceraan atau bisa diare. Sebaliknya bila makanan pendamping diberikan terlambat akan mengakibatkan anak kurang gizi. $^{8}$

\section{SIMPULAN}

Berdasarkan hasil penelitian maka didapatkan kesimpulan bahwa status gizi balita menurut indeks Berat badan menurut umur $(\mathrm{BB} / \mathrm{U})$ berdasarkan baku rujukan WHO-NHCS: Status gizi buruk tidak ada, Responden dalam penelitian yaitu Iibu-ibu dengan tingkat pendidikan SMA dan sebagian besar ibu-ibu bekerja sebagai ibu rumah tangga. Hal ini berpengaruh pada status gizi balita karena tingkat pendidikan dan status ekonomi yang rendah. Semakin 
tinggi pendidikan orang tua maka pengetahuannya tentang gizi akan lebih baik dibandingkan dengan yang berpendidikan kurang. Kurangnya perhatian pemberian makanan bergizi pada anak juga merupakan salah satu faktor penyebab terjadinya gizi kurang pada balita.

\section{SARAN}

Dapat memberikan penyuluhan kepada ibu-ibu yang mempunyai anak balita di PPA ID 127 (Pusat Pengembangan Anak) dan CSP CS-07 (Child Survival Programme) kelurahan Ranomut mengenai pentingnya meningkatkan status gizi dan tumbuh kembang anak balita untuk memperbaiki serta mengoptimalkan pemantauan gizi anak balita, serta pemberian makanan yang baik pada anak secara rutin. Perlunya penanganan dari PPA ID 127 (Pusat Pengembangan Anak) dan CSP CS-07 (Child Survival Programme) kelurahan Ranomut untuk lebih memperhatikan anak balita 0 59 bulan yang berstatus gizi kurang dan ditangani agar tidak menjadi gizi buruk.

\section{DAFTAR PUSTAKA}

1. Kemiskinan Kelaparan dan Kekurangan Gizi Adalah Masalah Kompleks [homepage on the Internet]. 2010 [cited 2011 Nov 11]. Available from: http://www.depkes.go.id/ index.php/berita/press-release/1108-kemis kinan-kelaparan-dan-kekurangan-gizi-ada lah-masalah-kompleks.html.

2. Aswar A. Gizi Seimbang Menuju Hidup Sehat bagi Balita. Jakarta: Departemen Kesehatan Dan Kesejahteraan RI, 2002; hal.124-6.

3. Badan Litbangkes, Depkes simnas IV [homepage on the Internet]. 2009. Available from: URL: http:/www.scribd.com/doc/1360077/resum e-hasil-kesehatan-dasar-indonesia

4. Ilmu Kesehatan Anak Fakultas Kedokteran Indonesia. Buku Kuliah 1 Ilmu Kesehatan Anak. Jakarta: Infomedika, 200; hal.314-6.

5. Windy R, Sari F, Ikeu N. 15 April 2009. Hubungan Status Gizi, Imunisasi Pada Anak Di Wilayah Puskesmas Ciawi Tasikmalaya [homepage on the Internet]. 2009 [updated 2009 Apr 15]. Available from URL: http//www.tasikmalayakab. go.id/component/option.com

6. Sulistyoningsih H. Gizi Untuk Kesehatan Anak.Yogyakarta: Graha Ilmu, 2011; hal.184-6.

7. Siswanto H. Pendidikan Kesehatan Anak Usia Dini. Yogyakarta: Purtaka Rihama, 2010; hal.126-8.

8. Widjaja MC. Gizi Tepat untuk Perkembangan Otak dan Kesehatan Balita. Jakarta: Kawan Pustaka, 2002; hal.87-89. 